\title{
PENERAPAN MODEL PEMBELAJARAN KOOPERATIF JIGSAW UNTUK MENINGKATKAN HASIL BELAJAR IPS
}

\author{
Ni Putu Suryanita SP ${ }^{1}$, Ni Nyoman Kusmariyatni ${ }^{2}$ \\ 1,2 Jurusan Pendidikan Guru Sekolah Dasar \\ Universitas Pendidikan Ganesha \\ Singaraja, Indonesia \\ e-mail: putusurya2612@gmail.com¹, nyoman.kusmariyatni@undiksha.ac.id ${ }^{2}$
}

\begin{abstract}
Abstrak
Penelitian ini bertujuan untuk meningkatkan hasil belajar IPS dengan menerapkan model pembelajaran kooperatif tipe Jigsaw pada siswa kelas IVA di SD Negeri 4 Kampung Baru tahun pelajaran 2017/2018. Jenis penelitian ini adalah penelitian tindakan kelas yang dilaksanakan dalam dua siklus. Setiap siklus terdiri atas tahap perencanaan, pelaksanaan tindakan, observasi dan evaluasi, serta refleksi. Pelaksanaan tindakan tiap siklus adalah tiga kali pertemuan. Subjek penelitian ini adalah siswa kelas IVA tahun pelajaran 2017/2018 di SD Negeri 4 Kampung Baru, yang berjumlah 26 orang. Objek penelitian ini adalah peningkatan hasil belajar IPS. Pengumpulan data dalam penelitian ini dilakukan denganmetode tes. Data dianalisis dengan metode analisis statistik deskriptif. Hasil penelitian menunjukkan bahwa terjadi peningkatan persentase hasil belajar pada siswa kelas IVA di SD Negeri 4 Kampung Baru. Berdasarkan tes hasil belajar, pada siklus I rata-rata hasil belajar IPS diperoleh sebesar 80,77 dengan kategori tinggi. Selanjutnya, pada siklus II rata-rata hasil belajar IPS diperoleh sebesar 86,37 dengan kategori tinggi. Berdasarkan perhitungan gains skor, kualitas peningkatan hasil belajar IPS pada siklus I sebesar 0,16 dengan predikat rendah dan siklus II sebesar 0,46 dengan predikat sedang. Berdasarkan hasil penelitian tersebut dapat disimpulkan bahwa penerapan model pembelajaran kooperatif tipe Jigsaw dapat meningkatkan hasil belajar IPS siswa siswa kelas IVA di SD Negeri 4 Kampung Baru tahun pelajaran 2017/2018.
\end{abstract}

Kata kunci: Model Pembelajaran Kooperatif tipe Jigsaw, Hasil Belajar IPS

\begin{abstract}
This research aims to improve the learning outcomes of IPS by applying Jigsaw type cooperative learning model in grade IVA students at SD Negeri 4 KampungBaru in the academic year 2017/2018. This type of research is a classroom action research conducted in two cycles. Each cycle consists of planning, implementation, observation and evaluation, and reflection. The implementation of each cycle is four meetings. The subjects of this study are students of class IVA academic year 2017/2018 in SD Negeri 4 KampungBaru, which amounted to 26 people. The object of this research is to improve learning outcomes of IPS. The data collection in this research is done by the test method. Data were analyzed by descriptive statistic analysis method. The results showed there is an increase percentage of learning outcomes in grade IVA studentsat SD Negeri 4 KampungBaru.Based on the test results, on first cyclelearning outcomes obtained by 80.77 with high category. Furthermore, in second cycle the learning outcomes of IPS obtained equal to 86,37 with high category.Based on the calculation of score gains, the quality of IPS learning achievement in first cycle was 0.16 with low predicate and second cycle was 0.46 with moderate predicate. Based on the result of the research, it can be concluded the implementation of Jigsaw type cooperative learning model can improve the learning outcomes of IPS on IVA grade students at SD Negeri 4 KampungBaru in academic year 2017/2018.
\end{abstract}

Keywords: Jigsaw Cooperative Learning Model, IPS Learning Outcomes 


\section{Pendahuluan}

Pendidikan mempunyai peranan yang penting bagi pembangunan suatu bangsa dan negara. Sumber daya manusia yang kompeten dapat dimanfaatkan untuk membantu kemajuan suatu negara. Untuk menciptakan sumber daya manusia yang cerdas dan kompeten maka sangat harus sejalan dengan peningkatan kualitas pendidikan yang diberikan kepada anggota masyarakat, khususnya peserta didik. Pendidikan bertanggung jawab dalam membina, mengembangkan serta meningkatkan kemampuan peserta didik. Jadi, pendidikan sangat mempengaruhi perkembangan dan perwujudan diri individu, terutama bagi pembangunan bangsa dan negara.

Pendidikan dilaksanakan dengan melalui proses belajar dan pendidik. Peserta didik atau siswa belajar dan guru mengajar dan mendidik. Proses belajar dan mengajar tersebut disebut dengan proses pembelajaran. Pembelajaran merupakan satu kegiatan yang melibatkan interaksi antara guru dan siswa, siswa dan siswa, serta siswa dan sumber belajar. Pembelajaran berlangsung sebagai suatu proses saling memengaruhi antara guru dan siswa ataupun antara siswa dengan siswa. Dalam hal ini, kegiatan yang terjadi adalah guru mengajar dan siswa belajar. Dengan adanya interaksi tersebut, siswa dapat membangun pengetahuan secara aktif dan mandiri, sehingga mencapai kompetensi yang diharapkan (Djamarah, 2006). Kompetensi yang dimaksud baik pada ranah afektif, kognitif maupun psikomotor.

Pada jenjang pendidikan sekolah dasar, siswa dibelajarkan sejumlah muatan pelajaran salah satu di antaranya adalah muatan pelajaran IImu Pengetahuan Sosial (IPS). Pembelajaran IPS memiliki kedudukan dan fungsi yang sangat penting dalam mempersiapkan dan membentuk individu yang mempunyai potensi, keberanian, dan memahami keberadaan dirinya sendiri dalam berinteraksi dengan lingkungan. Tjandra (2005:5), menyatakan "melalui pengajaran IPS peserta didik dapat memeroleh pengetahuan, keterampilan, sikap, dan kepekaan untuk menghadapi hidup dengan tantangan-tantangannya". Pembelajaran IPS hendaknya mampu mempersiapkan, membina, dan membentuk kemampuan peserta didik yang menguasai pengetahuan, sikap, nilai, dan kecakapan dasar yang diperlukan bagi kehidupan di masyarakat. Dengan demikian, diharapkan pencapaian hasil belajar IPS mencapai kriteria tinggi bahkan sangat tinggi. Dalam proses pembelajaran, hasil belajar dipengaruhi oleh beberapa faktor. Menurut Susanto (2013) faktor-faktor yang menentukan hasil belajar adalah yaitu: a) faktor internal, merupakan faktor yang bersumber dari dalam diri siswa, yang memengaruhi kemampuan belajarnya. Faktor internal ini meliputi: kecerdasan, kesiapan dan kematangan, bakat, minat, dan kemauan belajar, dan b) faktor eksternal, merupakan faktor berasal dari luar diri siswa yang memengaruhi hasil belajar yaitu, model penyajian materi pelajaran, pribadi dan sikap guru, suasana pengajaran, kompetensi guru, dan masyarakat.

Untuk menunjang tercapainya tujuan IPS tersebut harus didukung oleh iklim pembelajaran yang kondusif dan menyenangkan, karena iklim pembelajaran yang dikembangkan oleh guru mempunyai pengaruh yang sangat besar terhadap keberhasilan dan semangat belajar siswa.

Namun, pelaksanaan pembelajaran IPS di sekolah dasar masih mengalami kendala karena terdapat pemikiran siswa pelajaran IPS merupakan pembelajaran yang membosankan dan bersifat hafalan, sehingga siswa tidak tertarik pada pelajaran IPS. Kurangnya keterlibatan siswa juga memengaruhi proses pembelajaran. Adanya siswa yang pasif menyebabkan pembelajaran menjadi tidak efektif. Dengan keadaan yang demikian,dianggap guru belum bisa sepenuhnya melaksanakan pembelajaran yang melibatkan siswa secara aktif. Padahal kemampuan siswa terhadap IPS sangatlah penting, karena bekal pengetahuan sosial sangat menunjang pengalaman siswa untuk menghadapi kehidupan di masyarakat nantinya sesuai dengan tujuan pendidikan nasional yaitu menciptakan insan Indonesia cerdas dan kompetitif.

Berdasarkan hasil observasi yang dilakukan di kelas IVA di SDN 4 Kampung Baru pada tanggal 6 Pebruari 2018, dapat dilihat bahwa pada pembelajaran IPS, 1. siswa terlihat tidak antusias dalam mengikuti pembelajaran, 2. keaktifan siswa kurang, 3. terlihat beberapa siswa bercanda, dan tidak mengerjakan tugas-tugas yang diberikan oleh guru, 4. ruang kelas yang sempit dan panas sehingga mengganggu proses pembelajaran. Hal ini akan sangat 
berpengaruh terhadap hasil belajar siswa karena siswa tidak dapat menyerap materi pembelajaran dengan baik.

Berdasarkan hasil wawancara guru kelas IVA, menyatakan bahwa dalam pembelajaran IPS: 1. siswa sangat sulit diajak menghafal, 2. guru mengatakan bahwa pembelajaran sudah dilakukan dengan memberikan beberapa pertanyaan dan didiskusikan oleh siswa, namun tetap siswa kurang antusias, 3. siswa kadang tidak mau bertanya mengenai materi yang diajarkan, 4 . pada saat guru menjelaskan, terdapat beberapa siswa yang tidak fokus dan bercanda bersama temannya. Perilaku-perilaku ini muncul karena pembelajaran di kelas dirasakan tidak menyenangkan.

Hasil observasi dan hasil wawancara tersebut didukung oleh pencatatan dokumen yang didapat di sekolah. Berdasarkan pencatatan dokumen, rata-rata hasil belajar IPS siswa kelas IVA sudah berada di atas Kriteria Ketuntasan Minimal (KKM) yang ditetapkan yaitu 65. Namun, rata-rata hasil belajar IPS siswa Kelas IVA yang bernilai 79,04 tersebut baru mencapai kategori sedang apabila dibandingkan dengan kriteria PAP nasional. Dengan nilai yang demikian, maka sulit untuk mewujudkan tujuan pendidikan nasional yang menghendaki terciptanya insan Indonesia yang cerdas dan kompetitif. Untuk menjadi insan yang cerdas dan juga kompetitif, pencapaian hasil belajar siswa minimal pada kategori tinggi agar nantinya semua siswa dapat bersaing dalam kehidupan masyarakat. Dari 26 siswa, 13 siswa nilainya masih kategori sedang yaitu rentangan 65-79, 12 siswa nilainya kategori tinggi, dan 1 siswa nilainya kategori sangat tinggi. Hal ini berarti $50 \%$ siswa masih di bawah nilai rata-rata kelas dan memiliki kategori sedang. Hal ini sangat memerlukan suatu tindak lanjut.

Agar dapat meningkatkan hasil belajar siswa, maka perlu sebuah usaha perbaikan atau tindakan untuk menindaklanjuti hal tersebut. Salah satu upaya yang dapat dilakukan untuk meningkatkan hasil belajar adalah dengan menggunakan model pembelajaran. Model pembelajaran yang mampu meningkatkan minat siswa dalam mengikuti pembelajaran sehingga materi pembelajaran dapat terserap atau dapat dipahami dengan baik dan dapat meningkatkan hasil belajarnya. Salah satu model pembelajaran yang dapat dijadikan solusi adalah model pembelajaran kooperatif tipe jigsaw.

Model pembelajaran kooperatif tipe jigsaw merupakan salah satu tipe pembelajaran kooperatif yang mendorong siswa aktif dan saling membantu dalam penguasaan materi pelajaran untuk mencapai prestasi yang maksimal. Menurut Kurniawasih dan Berlin (2015), "Jigsaw adalah model kooperatif yang didesain untuk meningkatkan rasa tanggung jawab siswa terhadap pembelajarannya sendiri dan juga pembelajaran orang lain". Artinya siswa tidak hanya mempelajari materi yang diberikan, namun siswa juga harus siap memberikan dan mengajarkan materi yang dikuasainya kepada anggota kelompoknya. Sejalan dengan itu, Menurut Isjoni (2009:77) pembelajaran kooperatif tipe jigsaw merupakan salah satu tipe pembelajaran kooperatif yang mendorong siswa aktif dan saling membantu dalam penguasaan materi pelajaran untuk mencapai prestasi yang maksimal. Pada kegiatan ini keterlibatan guru dalam proses belajar mengajar semakin berkurang dalam arti guru menjadi pusat kegiatan kelas. Guru berperan sebagai fasilitator yang mengarahkan dan memotivasi siswa untuk belajar mandiri serta menumbuhkan rasa tanggungjawab. Bertolak dari hal tersebut, maka dalam pemerapan model ini keaktifan siswa sangat dibutuhkan. Siswa dikelompokkan menjadi beberapa kelompok yang beranggotakan 3-5 orang yang terdiri dari kelompok asal dan kelompok ahli. Siswa memiliki banyak kesempatan untuk mengemukakan pendapat, mengolah informasi yang didapat dan dapat meningkatkan komunikasi antar anggota kelompok, memiliki rasa tanggung jawab terhadap keberhasilan kelompoknya dan ketuntasan bagian materi yang dipelajari, serta dapat menyampaikan informasi yang didapat dari kelompok lain. Jadi, dalam penerapan model ini, keaktifan siswa sangat jelas terlihat di dalam kelas. Ssiwa mampu membangun pengetahuannya berdasarkan hasil diskusi dan berbagi informasi antar kelompok, sehingga nantinya akan berdampak pada hasil belajar siswa.

Dalam penerapan model pembelajaran kooperatif tipe jigsaw, untuk meningkatkan hasil belajar siswa pada pembelajaran IPS, dapat dibantu dengan menggunakan berbagai macam media, salah satunya adalah media video pembelajaran. Media video pembelajaran merupakan jenis media audio visual yang menyajikan pesan pembelajaran baik yang berisi konsep, prinsip, 
prosedur, teori aplikasi pengetahuan untuk membantu pemahaman terhadap suatu materi pembelajaran dalam bentuk gambar dan suara. Mahadewi, dkk (2006:4) menyatakan bahwa media video pembelajaran dapat diartikan sebagai "media yang digunakan untuk merangsang pikiran, perasaan dan kemauan siswa untuk belajar melalui penayangan ide atau gagasan, pesan dan informasi secara audio visual". Dengan menggunakan media video pembelajaran, dapat merangsang pikiran, perasaan, dan kemauan siswa untuk belajar. Selain itu, media video pembelajaran tidak dibatasi oleh ruang dan waktu, karena media video dapat menampilkan masa lalu dan masa sekarang, pesan yang berukuran besar atau kecil, memiliki kecepatan tinggi atau rendah, dan berwarna atau tidak berwarna. Dengan mengkombinasikan model pembelajaran kooperatif tipe jigsaw dengan media video pembelajaran pada muatan pelajaran IPS, diharapkan dapat menarik perhatian siswa dalam proses pembelajaran sehingga dapat meningkatkan hasil belajar siswa.

Berdasarkan hal tersebut, muncul-lah pertanyaan apakah penerapan model pembelajaran kooperatif Jigsaw dapat meningkatkan hasil belajar IPS siswa kelas IVA SDN 4 Kampung Baru Tahun Pelajaran 2017/2018? Oleh karena itu, dilaksanakannya penelitian di SDN 4 Kampung Baru ini yang bertujuan untuk mengetahui peningkatan hasil belajar IPS setelah menerapkan model pembelajaran kooperatif Jigsaw pada siswa kelas IVA SDN 4 Kampung Baru Tahun Pelajaran 2017/2018.

\section{Metode}

Berdasarkan karekterikstik masalah yang diteliti, penelitian ini dapat dikla-sifikasikan ke dalam penelitian tindakan kelas (PTK) karena penelitian ini digunakan untuk memecahkan masalah pembelajaran di kelas. Penelitian ini juga termasuk penelitian deskriptif karena menggambarkan penerapan suatu pembelajaran untuk meningkatkan hasil belajar.

Subjek dalam penelitian ini adalah siswa kelas IV A di SDN 4 Kampung Baru Tahun Ajaran 2017/2018 yang berjumlah 26 orang siswa. Objek penelitian ini adalah hasil belajar kognitif IPS siswa kelas IV A . di SDN 4 Kampung Baru Tahun Ajaran 2017/2018.

Penelitian ini bertujuan untuk meningkatkan hasil belajar IPS siswa. Dalam penelitian ini terdapat dua variabel yang dikaji, yaitu variabel bebas dan variabel terikat. Yang menjadi variabel bebas adalah model pembelajaran kooperatif tipe jigsaw $(X)$ dan yang menjadi variabel terikat adalah hasil belajar IPS (Y). variabel bebas akan memengaruhi variabel terikat.
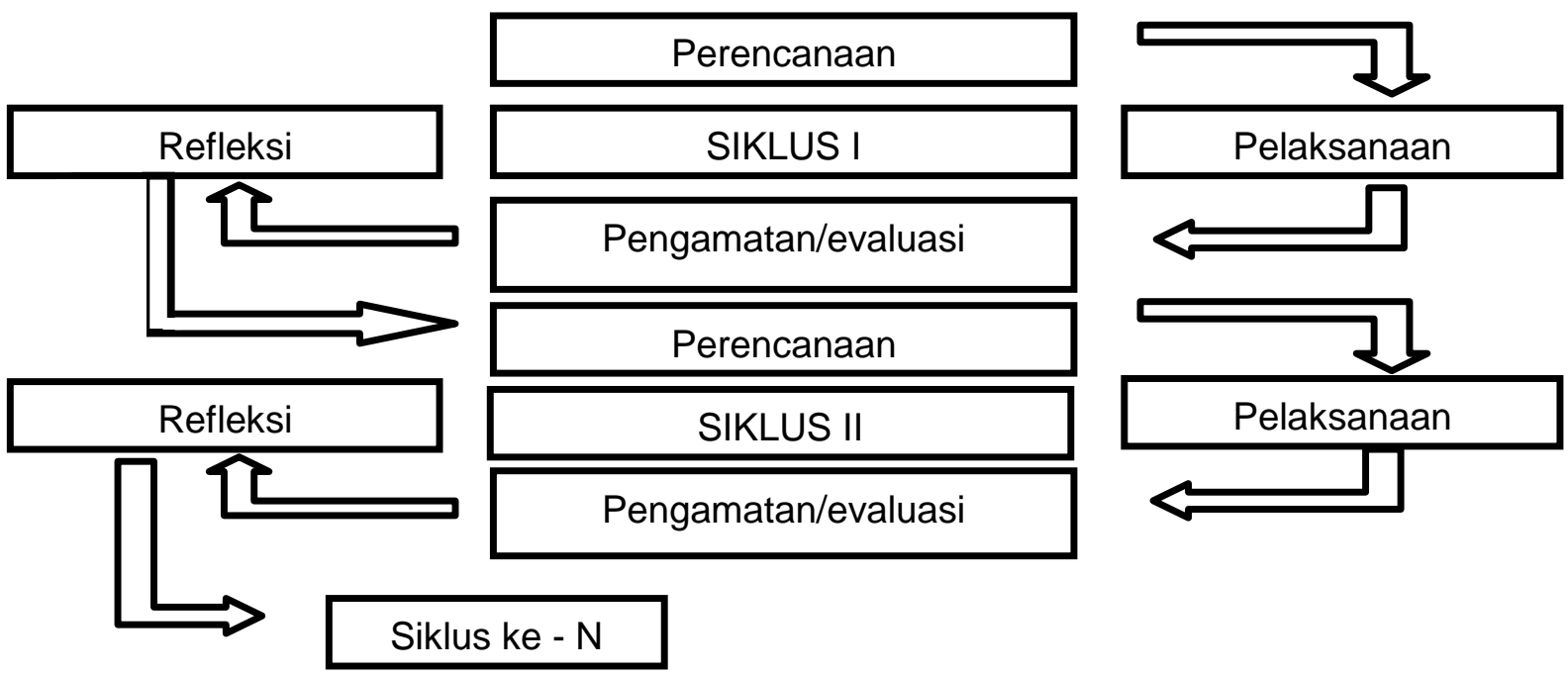

Gambar 1 Siklus PTK (Arikunto, dkk, 2012) 


\section{Penelitian ini dilakukan dengan tahapan-tahapan sebagai berikut. \\ a. Perencanaan}

Perencanaan tindakan adalah perencanaan yang dilakukan untuk memperbaiki proses pembelajaran. Sesuai dengan permasalahan yang muncul di kelas IV, yaitu hasil belajar siswa masih pada kategori sedang pada mata pelajaran IPS, maka perlu diterapkan model pembelajaran kooperatif tipe jigsaw berbantuan media video pembelajaran sehingga kegiatan pembelajaran dapat berjalan dengan baik. Adapun kegiatan-kegiatan yang dilakukan pada tahap perencanaan adalah sebagai berikut.

1) Mengidentitikasi masalah.

2) Menganalisis dan merumuskan masalah.

3) Meminta izin kepada kepala SDN 1 Tukadmungga untuk mengadakan penelitian.

4) Mendiskusikan model pembelajaran project based learning kepada guru sebagai observer.

5) Bersama-sama guru mengembangkan silabus mengenai materi yang akan dipelajari.

6) Bersama-sama guru mencermati materi pelajaran yang terdapat dalam kurikulum pada semester pelaksanaan penelitian yang dapat dipilih untuk kepentingan penelitian.

7) Bersama-sama guru merumuskan indikator pembelajaran sebagai pembatasan tentang apa yang diharapkan dapat dipahami siswa setelah mengikuti pembelajaran yang didasarkan pada standar kompetensi mata pelajaran.

8) Bersama-sama guru menyusun rencana pembelajaran (RPP) menggunakan model pembelajaran project based learning berbantuan media video pembelajaran sesuai dengan materi yang akan diajarkan.

9) Mempersiapkan instrumen penelitian yang terdiri dari lembar observasi aktivitas belajar dan hasil belajar.

b. Pelaksanaan

Pelaksnaan adalah upaya yang dilakukan oleh guru/peneliti melakukan perbaikan atau peningkatan yang digunakan. Adapun langkah-langkah kegiatan pembelajaran secara umum adalah sebagai berikut.

1) Melaksanakan kegiatan pembelajaran dengan menerapkan model pembelajaran project based learning berbantuan media video pembelajaran untuk meningkatkan aktivitas belajar dan hasil belajar IPA sesuai dengan perencanaan.

2) Membimbing dan mengarahkan siswa pada saat proses pembelajaran berlangsung.

3) Memfasilitasi siswa dalam pembuatan proyek.

c. Pengamatan atau Evaluasi

Pengamatan dilakukan untuk mengetahui kesesuaian antara perencanaan dan pelaksanaan tindakan. Pengamatan dilaksanakan dari awal sampai akhir pembelajaran. Hasil pengamatan dituangkan dalam bentuk catatan sebagai bahan refeksi. Evaluasi dilakukan untuk mengetahui dampak model pembelajaran kooperatif tipe jigsaw berbantuan media video pembelajaran.

Kegiatan yang dilakukan pada tahap ini adalah memberikan evaluasi setiap akhir siklus untuk mengetahui terjadinya peningkatan hasil belajar. Evaluasi hasil belajar siswa berpedoman pada kriteria penilaian.

d. Refleksi

Pada akhir siklus ini, dilakukan refleksi untuk merenungkan dan mengkaji hasil tindakan pada siklus I mengenai hasil belajar IPS. Peneliti bersama guru melakukan refleksi yang berpedoman kepada hasil evaluasi dan observasi, serta kendala-kendala yang diperoleh selama pelaksanaan kegiatan siklus I. Dengan hasil refleksi ini, peneliti bersama guru mencoba merumuskan tindakan baru sebagai penyempurnaan terhadap tindakan yang telah dilakukan. Alternatif tindakan baru ini akan ditetapkan menjadi tindakan baru pada rencana tindakan dalam penelitian tindakan kelas siklus berikutnya.

Data yang dikumpulkan dalam penelitian ini adalah data tentang hasil belajar IPS siswa. Untuk memeroleh data tersebut, digunakan metode tes berbentuk tes tulis yang digunakan untuk mengetahui hasil belajar IPS siswa. Instrument yang digunakan berupa tes berbentuk 
pilihan ganda dengan menggunakan empat pilihan, yaitu a, b, c, dan d serta tes berbentuk isian singkat. Tes dalam penelitian ini dibuat berdasarkan kisi-kisi yang telah dibuat sebelumnya.

Data penelitian yang telah berkumpul selanjutnya dianalisis. Dalam menganalisis data ini digunakan metode analisis statistik deskriptif dan analisis deskriptif kuantitatif.

Dalam penerapan analisis statistik deskriptif, data yang diperoleh dari hasil penelitian dihitung mean atau rata-ratanya. Data hasil belajar IPS yang diperoleh setelah dilakukan tes, selanjutnya data hasil belajar dianalisis sebagai berikut.

a. Analisis Data Hasil Belajar IPS secara Individu

Nilai $=\frac{\text { Skor Perolehan Tes Hasil Belajar }}{\text { Skor Maksimal }} \times 100$

b. Analisis Rata-rata Hasil Belajar IPS secara Klasikal

$$
\begin{array}{ll}
\underset{M=\frac{2}{N}}{(\text { Koyan }} & \\
& \text { Keterangan: } \\
M & =\text { Nilai rata-rata } \\
\sum_{N} X & =\text { Jumlah nilai seluruh siswa } \\
& =\text { Banyaknya siswa }
\end{array}
$$

Untuk mencari persentase tingkat hasil belajar digunakan rumus sebagai berikut.

$$
M \%=\frac{M}{S M I} x 100 \%
$$

Keterangan:

$$
\begin{array}{ll}
M \% & =\text { Rata-ratapersentase } \\
M & =\text { Mean } \\
\text { SMI } & =\text { Skor maksimal ideal }
\end{array}
$$

Hasil analisis persentase hasil belajar siswa yang diperolah selanjutnya dikonversikan ke dalam Patokan Acuan Penilaian (PAP) skala lima dengan berpedoman pada kriteria tabel berikut.

Tabel 1. Kategori Penggolongan Data Hasil Belajar

\begin{tabular}{ccc}
\hline $\begin{array}{c}\text { Rentangan Skor (\%) } \\
85 \leq M \leq 100\end{array}$ & $\begin{array}{c}\text { Kategori Aktivitas Belajar } \\
\text { Sangat Aktif }\end{array}$ & $\begin{array}{c}\text { Hasil Belajar } \\
\text { Sangat Baik }\end{array}$ \\
\hline $70 \leq M<85$ & Aktif & Baik \\
$50 \leq M<70$ & Cukup Aktif \\
$30 \leq M<50$ & $\begin{array}{c}\text { Kurang Aktif } \\
\text { Sangat } \\
\text { Kurang Aktif }\end{array}$ & Kurang Baik \\
$0 \leq M<30$ & Sangat Kurang Baik
\end{tabular}

(Sumber: Dimodifikasi dari Agung, 2014)

Peningkatan hasil belajar ditentukan dengan membandingkan skor yang diperoleh pada pra-siklus, siklus I, dan siklus II. Peningkatan tersebut dihitung dengan rumus gains skor ternormalisasi sebagai beriku.

$\boldsymbol{G n}=\frac{\text { Spost }- \text { Spre }}{\text { Smax }- \text { Spre }}$ (Agung 2016:141) 
Keterangan:

$\begin{array}{ll}\text { Gn } & =\text { Gains skor } \\ \text { Spost } & =\text { Skor akhir } \\ \text { Spre } & =\text { Skor awal } \\ \text { Smax } & =\text { Skor maksimal ideal }\end{array}$

Untuk menentukan keberhasilan tindakan meningkatkan hasil belajar IPS digunakan kriteria pada tabel 4 berikut.

Tabel 2. Kriteria Peningkatan Hasil Belajar pada Mata Pelajaran IPS

\begin{tabular}{cc}
\hline Kriteria Peningkatan Gains Skor & Predikat \\
\hline$G n \geq 0,7$ & Tinggi \\
$0,3 \leq G n<0,7$ & Sedang \\
$G n<0,3$ & Rendah \\
\hline
\end{tabular}

Indikator keberhasilan penelitian tindakan kelas ini untuk meningkatkan hasil belajar IPS siswa kelas IV SDN 4 Kampung Baru. Keberhasilan penelitian tindakan ini ditandai dengan adanya peningkatan hasil belajar IPS siswa ke arah yang lebih baik. Indikator keberhasilan penelitian ini adalah sebagai berikut.

a. Persentase rata-rata hasil belajar IPS siswa minimal berada pada rentang $80 \leq \mathrm{M}<90$ dengan kriteria tinggi.

b. Kualitas peningkatan hasil belajar IPS siswa berada pada rentangan $0,3 \leq G n<0,7$, yakni mencapai predikat minimal sedang.

c. Ketuntasan klasikal siswa minimal $70 \%$, artinya minimal $70 \%$ siswa memeroleh nilai di minimal 80.

\section{Hasil dan Pembahasan}

Deskripsi data hasil belajar IPS siswa siklus I dan Siklus II memaparkan mengenai jumlah siswa, mean, skor terendah, skor tertinggi, jumlah siswa yang tuntas, jumlah siswa yang tidak tuntas, dan ketuntasan klasikal. Hasil perhitungan disajikan pada tabel 3 dan tabel 4.

Tabel 3 Data hasil Belajar IPS Siswa pada Siklus I

\begin{tabular}{clc}
\hline No & \multicolumn{1}{c}{ Aspek } & Keterangan Nilai \\
\hline 1 & Jumlah Siswa & 26 \\
2 & Mean & 80.77 \\
3 & Skor Terendah & 65 \\
4 & Skor Tertinggi & 100 \\
5 & Jumlah Siswa Tidak Tuntas & 11 \\
6 & Jumlah Siswa Tuntas & 15 \\
7 & Ketuntasan Klasikal & $58 \%$ \\
\hline
\end{tabular}

Berdasarkan tabel 3, jumlah siswa adalah 26 orang dan seluruhnya mengikuti tes. Jumlah nilai yang diperoleh dari keseluruhan siswa adalah 2100 sehingga rata-rata nilai siswa adalah 80.77 memiliki kriteria tinggi. Nilai terendah yang diperoleh siswa adalah 65 dan nilai tertinggi adalah 100. Siswa yang tuntas 15 siswa dan yang tidak tuntas ada 11 siswa dengan persentase ketuntasan klasikal mencapai 58\%.

Peningkatan Prasiklus ke Siklus I

$$
\mathrm{Gn}=\left[\frac{\text { Spost }- \text { Spre }}{\text { Smax }- \text { Spre }}\right]
$$




$$
\begin{aligned}
& G n=\left[\frac{58-50}{100-50}\right] \\
& G n=0,16
\end{aligned}
$$

Hasil yang diperoleh tersebut belum mencapai indikator keberhasilan untuk hasil belajar kognitif siswa yang telah ditetapkan dalam penelitian ini yaitu mencapai predikat minimal sedang dengan kriteria 0,30-0,69. Peningkatan masih dalam kategori rendah yaitu 0,16 (predikat rendah) sehingga masih perlu adanya peningkatan yang akan dilaksanakan pada siklus II.

Tabel 4 Data Hasil Belajar IPS Siswa pada Siklus II

\begin{tabular}{clc}
\hline No & \multicolumn{1}{c}{ Aspek } & Keterangan Nilai \\
\hline 1 & Jumlah Siswa & 26 \\
2 & Mean & 86.37 \\
3 & Skor Terendah & 66 \\
4 & Skor Tertinggi & 100 \\
5 & Jumlah Siswa Tidak Tuntas & 19 \\
6 & Jumlah Siswa Tuntas & 7 \\
7 & Ketuntasan Klasikal & $73 \%$ \\
\hline
\end{tabular}

Berdasarkan tabel 4.3, jumlah siswa adalah 26 orang dan seluruhnya mengikuti tes. Jumlah nilai yang diperoleh dari keseluruhan siswa adalah 2246 sehingga rata-rata nilai siswa adalah 86,37 memiliki kriteria tinggi. Nilai terendah yang diperoleh siswa adalah 66 dan nilai tertinggi adalah 100. Siswa yang tuntas 19 siswa dan yang tidak tuntas ada 7 siswa dengan persentase ketuntasan klasikal mencapai $73 \%$.

Peningkatan Pra Siklus ke Siklus II

$$
\begin{aligned}
& \mathrm{Gn}_{\mathrm{n}}=\left[\frac{\text { Spost }- \text { Spre }}{\text { S max }- \text { Spre }}\right] \\
& \mathrm{Gn}_{\mathrm{n}}=\left[\frac{73-50}{100-50}\right]
\end{aligned}
$$

$\mathrm{Gn}=0,46$

Hasil yang diperoleh pada siklus II tersebut telah mencapai indikator keberhasilan untuk hasil belajar siswa yang telah ditetapkan dalam penelitian ini yaitu peningkatan mencapai predikat minimal sedang dengan kriteria 0,30-0,69. Peningkatan dalam kategori sedang yaitu 0,46 .

Penelitian yang sudah dilakukan pada siklus II mengenai hasil belajar IPS siswa telah mengalami peningkatan serta telah berlangsung dengan baik. Tanggapan siswa terhadap pembelajaran yang telah dilaksanakan sangat baik.

Berdasarkan penjabaran di atas, indikator keberhasilan penelitian yang meliputi hasil belajar IPS siswa telah tercapai. Sehingga penelitian ini dikatakan berhasil dan penelitiaan ini hanya dilaksanakan dalam 2 siklus.

Penelitian Tidakan Kelas (PTK) ini dilaksanakan sebagai upaya untuk meningkatkan hasil belajar siswa dengan menggunakan model pembelajaran kooperatif tipe jigsaw. Prosedur penelitian yang digunakan adalah prosedur penelitian tindakan kelas yang dilaksanakan dalam bentuk siklus. Dalam penelitian ini digunakan dua siklus yang masing-masing siklus terdiri dari dua kali pertemuan dan setiap siklus dilaksanakan sesuai dengan skenario yang telah dibuat dan memuat empat tahap kegiatan yaitu tahap perencanaan, tahap pelaksanaan tindakan, tahap observasi dan evaluasi yang dilanjutkan dengan tahap refleksi.

Hasil penelitian ini menunjukkan bahwa penerapan model pembelajaran kooperatif tipe Jigsaw yang dalam pengaplikasiannya dibantu dengan media video pembelajaran, dapat meningkatkan hasil belajar IPS siswa kelas IVA SDN 4 Kampung Baru dari siklus I ke siklus II. 
Hasil belajar IPS yang diperoleh pada siklus I belum memenuhi kriteria keberhasilan yang telah ditentukan. Sedangkan, hasil belajar IPS yang diperoleh pada siklus II, menunjukkan persentase rata-rata hasil belajar memenuhi kriteria keberhasilan yang telah ditentukan.

Berdasarkan hasil analisis data pelaksanaan tindakan pada siklus I menunjukkan bahwa peningkatan hasil belajar siswa belum mencapai indikator keberhasilan yang diinginkan. Terdapat kekurangan yang diperoleh dari hasil refleksi dalam proses pembelajaran pada siklus pertama, seperti siswa kurang serius dan sering membuat gaduh terutama ketika pembentukan kelompok ahli dan siswa yang kemampuannya kurang sulit mengerjakan tugas yang diberikan. Perlu adanya perbaikan pada kekurangan tersebut. Terlepas dari hal itu, proses pembelajaran melalui penerapan model pembelajaran kooperatif tipe jigsaw yang dibantu dengan pengunaan madia video pembelajaran sudah menunjukkan adanya kelebihan yang terlihat dari beberapa hal sebagai berikut.

1. Perhatian siswa terpusat pada materi yang dipelajari.

2. Semangat dan antusiasme siswa yang tinggi serta tertarik mengikuti pelajaran.

3. Komunikasi antar siswa sudah mulai terlihat dalam kerja kelompok.

4. Siswa yang memiliki kemampuan lebih mau membantu temannya yang masih kurang.

Berdasarkan keterangan di atas mengenai adanya kekurangan yang perlu diperbaiki serta kelebihan yang perlu dipertahankan atau ditingkatkan, maka tindakan perbaikan yang dilaksanakan pada siklus II antara lain sebagai berikut.

1. Guru lebih mengawasi siswa agar lebih tertib, serius dalam belajar, tidak membuat gaduh, serta selalu memperhatikan dan menyimak temannya yang sedang bertanya atau mempresentasikan hasil kerjanya.

2. Guru lebih memotivasi siswa dalam proses pembelajaran dengan memberikan reward secara visual atau nonvisual agar siswa berani mengajukan pertanyaan kepada guru maupun temannya serta berdiskusi dengan temannya.

3. Guru hendaknya meminta siswa untuk mempelajari materi yang sudah dibahas agar tidak lupa serta memberikan pesan moral kepada siswa terkait materi pembelajaran.

Adapun hasil pembelajaran pada siklus II setelah melaksanakan tindakan perbaikan mengalami peningkatan dan terlaksana dengan baik. Hal ini terlihat dari peningkatan hasil hasil belajar siswa, nilai rata-rata pada siklus I sejumlah 80.77 , persentase ketuntasan klasikal $58 \%$ dengan predikat peningkatan rendah yaitu 0,16 meningkat menjadi rata-rata 86,37 berkriteria tinggi, ketuntasan klasikal mencapai $73 \%$ dengan predikat peningkatan sedang yaitu 0,46 pada siklus II.

Berdasarkan data di atas, terdapat peningkatan hasil belajar IPS dari siklus I ke siklus II. Peningkatan hasil belajar IPS disebabkan oleh beberapa faktor.

Pertama, penerapan model pembelajaran kooperatif tipe Jigsaw siswa diajak belajar berdiskusi dengan baik dan bertanggungjawab pada pekerjaan yang diberikan kepada siswa. Dengan penerapan model pembelajaran tersebut, siswa berusaha mempelajari materi agar dapat menyelesaikan tugas yang menjadi tanggungjawabnya dengan baik. Penerapan model ini juga mendorong siswa aktif berbagi informasi agar dapat mencapai prestasi kelompok yang maksimal. Hal ini sejalan dengan pendapat Isjoni (2009) pembelajaran kooperatif tipe jigsaw merupakan salah satu tipe pembelajaran kooperatif yang mendorong siswa aktif dan saling membantu dalam penguasaan materi pelajaran untuk mencapai prestasi yang maksimal. Dengan demikian, siswa berusa sebaik mungkin agar dapat menampilkan presentasi kelompok yang baik di depan teman-temannya di kelompok lain.

Kedua, siswa mengamati video pembelajaran yang berkaitan dengan materi pelajaran. Siswa dapat mengamati video pembelajaran dengan baik. Melalui kegiatan pengamatan siswa dapat mengkonstruksi pengetahuannya sendiri. Hal ini sesuai dengan pernyataan Albert Bandura (dalam Sani, 2014a:35) yang menyatakan bahwa "peserta didik belajar melalui pengamatan atau berdasarkan apa yang mereka saksikan". Siswa dapat belajar dari mengamati video pembelajaran yang terkait dengan materi pelajaran. Kegiatan mengamati video pembelajaran, dapat memudahkan siswa mengumpulkan informasi terkait dengan materi yang akan dipelajari, sehingga dapat membantu siswa belajar dengan baik. Media video pembelajaran dapat membantu siswa memperjelas suatu konsep dan dapat memahami materi 
pelajaran, sehingga dapat meningkatkan hasil belajar. Hasil penelitian ini didukung oleh pernyataan Mahadewi, dkk (2006:7) yang menyatakan bahwa "suatu konsep yang abstrak atau tidak bisa dihadirkan ke kelas secara langsung, dapat diatasi melalui sajian media video pembelajaran sehingga konsep yang diterima siswa menjadi jelas dan mudah dipahami siswa".

Ketiga, peningkatan hasil belajar IPS disebabkan oleh aktivitas belajar siswa. Siswa melakukan berbagai aktivitas belajar selama proses pembelajaran berlangsung. Siswa melakukan aktivitas belajar, seperti membaca buku, memperhatikan penjelasan guru, mendengarkan persentasi kelompok lain, tanya-jawab, mengemukakan pendapat, memberikan saran, mengamati media video pembelajaran, dan mengikuti setiap tahap proses pembelajaran. Siswa dapat melakukan aktivitas belajar dengan baik, sehingga dapat meningkatkan hasil belajar IPS. Aktivitas belajar yang dilakukan siswa dapat meningkatkan pemahaman materi yang dipelajari sehingga hasil belajar siswa meningkat. Hal ini sesuai dengan pernyataan Suhana (2014) menyatakan bahwa aktivitas belajar dapat memberikan nilai tambah bagi peserta didik untuk menumbuhkembangkan pemahaman terhadap materi yang dipelajari.

Hasil penelitian ini didukung oleh beberapa penelitian yang relevan yang pernah menggunakan model pembelajaran kooperatif tipe jigsaw dan media video pembelajaran. Penelitian oleh Susilowati (2012) yang berjudul "Peningkatan Prestasi Belajar Siswa pada Mata Pelajaran IPS melalui Pembelajaran Jigsaw pada Kelas VII H Semester Gasal SMP 2 Semarang Tahun Pelajaran 2012/2013". Hasil penelitian ini menunjukkan bahwa terdapat peningkatan jumlah perolehan nilai dari kurang $70 \%$ menjadi lebih dari $85 \%$ dan dapat meningkatkan perolehan nilai IPS siswanya.

Penelitian dari Lewis (2012) yang berjudul "The Effects of Jigsaw Learning on Students' Attitudes Vietnamese Higer Education Classroom". Hasil penelitian ini menunjukkan bahwa terlihat indikasi bahwa siswa secara umum lebih bekerjasama dengan siswa lain dan saling memberi pertolongan, berdiskusi dan berbagi informasi serta memberikan pengajaran pada siswa lain, sehingga dapat berkontribusi terhadap ingatan pengetahuan siswa.

Penelitian lainnya yaitu penelitian oleh Supryadi (2013) yang berjudul "Penerapan Media Video Pembelajaran sebagai Aplikasi Pendekatan Contekstual Teaching Learning untuk meningkatkan Hasil Belajar IPA Siswa Kelas V". Hasil penelitian ini menunjukkan bahwa terdapat peningkatan hasil belajar IPA.

\section{Simpulan dan Saran}

Berdasarkan penelitian yang telah dilakukan pada siswa kelas IVA SD Negeri 4 Kampung Baru tahun pelajaran 2017/2018, maka dapat disimpulkan bahwa pembelajaran dengan penerapan model pembelajaran kooperatif tipe Jigsaw terbukti dapat meningkatkan hasil belajar IPS siswa. Hal ini dibuktikan dengan adanya peningkatan hasil belajar IPS secara klasikal yang dilakukan dari siklus I ke siklus II. Nilai rata-rata 80.77 pada siklus I meningkat menjadi 86,37 pada siklus II, ketuntasan klasikal meningkat dari $58 \%$ pada siklus I menjadi $73 \%$ pada siklus II, kualitas peningkatan hasil belajar adalah 0,16 pada siklus I meningkat menjadi 0,46 pada siklus II.

Berdasarkan hasil penelitian ini, maka dapat diajukan saran: 1) kepada kepala sekolah hendaknya selalu memonitoring proses pembelajaran agar dapat menciptakan inovasi pembelajaran yang dapat meningkatkan aktivitas belajar siswa yang nantinya akan berpengaruh pada hasil belajar siswa; 2) kepada guru hendaknya menerapkan model pembelajaran ini sebagai salah satu alternatif pembelajaran dalam upaya meningkatkan hasil belajar siswa; 3) kepada siswa hendaknya senantiasa aktif selama proses pembelajaran berlangsung, sehingga dapat meningkatkan hasil belajar; dan 4) kepada peneliti lain yang berminat terhadap temuan penelitian ini dapat mencoba mengembangkan penerapan model pembelajaran kooperatif tipe Jigsaw pada materi atau kompetensi yang lain, serta menjadikan kekurangan-kekurangan pada penelitian ini sebagai bahan pertimbangan dalam merencanakan penelitian, sehingga hasil penelitian menjadi lebih baik. 


\section{Daftar Rujukan}

Agung, Anak Agung Gede. 2016. Staristika Dasar untuk Pendidikan. Yogyakarta: Deepublish. Arikunto, Suharsimi, dkk. 2012. Penelitian Tindalak Kelas. Jakarta: Bumi Aksara.

Djamarah, Syaiful Bahri dan Awan Zain. 2006. Strategi Belajar Mengajar. Jakarta: PT Rineka Cipta.

Isjoni. 2009. Cooperative Learning Efektifitas Pembelajaran Kelompok. Bandung: Alfabeta.

Koyan, I Wayan. 2012. Statistik Pendidikan: Teknik Analisis Data Kuantitatif. Singaraja: Undiksha Press.

Kurniawasih, Imas dan Berlin Sani. Ragam Pengembangan Model Pembelajaran. Jakarta: Kata Pena.

Lewis, Ramon. 2012. "The Effects of Jigsaw Learning on Students' Attitudes in a Vietnamese Higher Education Classroom". International Journal of Higher Education. Vol. 1, No. 2 (hlm. 9-20).

Mahadewi, Luh Putu Putrini, dkk. 2006. Media Video Pembelajaran. Singaraja: Jurusan Teknologi Pendidikan Fakultas IImu Pendidikan Universitas Pendidikan Ganesha.

Sani, Ridwan Abdullah. 2014a. Pembelajaran Saintifik untuk Implementasi Kurikulum 2013. Jakarta PT Bumi Aksara.

Suhana, Cucu. 2014. Konsep Strategi Pembelajaran. Bandung: PT Refika Aditama.

Supryadi, Pt. Eka. 2013. "Penerapan Media Video Pembelajaran sebagai Aplikasi Pendekatan Contekstual Teaching Learning Untuk Meningkatkan Hasil Belajar IPA Siswa Kelas V". Tersedia:

http://ejournal.undiksha.ac.id /index.php/JJPGSD/article/view/1492/1353.Diakses, 07 pebruari 2018.

Susanto, Ahmad. 2013. Teori Belajar dan Pembelajaran Di Sekolah Dasar. Jakarta: Kencana Prenadamedia Group.

Susilowati, Sri. 2012. "Peningkatan Prestasi Belajar Siswa pasa Mata Pelajaran IPS melalui Pembelajaran Jigsaw pada Kelas VII H Semester Gasal SMP 2 Semarang Tahun Pelajaran 2012/2013". Media Penelitian Pendidikan. Vol. 6, No. 2 (hlm. 45-59).

Tjandra, Made, dkk. 2005. Pendidikan Ilmu Pengetahuan Sosial di Sekolah Dasar. Bahan Ajar. Singaraja: Jurusan Pendidikan Dasar, Fakultas IImu Pendidikan IKIPN Singaraja. 